\title{
SATISFACTION AT IFES: AN ANALYSIS THROUGH CAREER ANCHORS
}

\author{
ROSÂNGELA C. VARGAS ${ }^{1}$ \\ https://orcid.org/0000-0001-7009-1612 \\ ARIDELMO TEIXEIRA ${ }^{2}$ \\ https://orcid.org/0000-0002-4909-1025
}

To cite this paper: Vargas, R. C., \& Teixeira, A. (2018). Satisfaction at IFES: An analysis through career anchors. Revista de Administração Mackenzie, 19(3). doi:10.1590/1678-6971/eRAMG180101

Submission: Sept. 26, 2017. Acceptance: Dec. 19, 2017.

Instituto Federal do Espírito Santo (IFES), Vitória, ES, Brazil.

2 Fundação Instituto Capixaba de Pesquisa em Contabilidade Economia e Finanças (Fucape), Vitória, ES, Brazil.

\section{(cc) BY}




\section{ABSTRACT}

Purpose: The objective of this research is to analyze the job satisfaction of public servants through career anchors.

Originality/value: The contribution of this research is to apply a collection instrument in reduced version for the analysis of job satisfaction in the public service in the search of subsidies for proposals of improvements in work processes related to people management.

Design/methodology/approach: We conducted the research with 671 public servants from the public education area. As an instrument of collection, we sent questionnaires using the electronic survey method and on paper. We based the questionnaire on the "Career Anchor Inventory" - adapted by Igbaria and Baroudi (1993) and the work by Netemeyer, Boles, and McMurrian (1996), termed as "Global Job Satisfaction".

Findings: The Security/Stability anchor obtained significant explanatory power with job satisfaction, but its representativeness was not the largest in the sample. Our practical contribution will be in the support to the construction of policies of people management, since the results indicated lower rates of satisfaction with regard to the aspects of promotion and with respect to the relationship with senior management.

\section{KEYWORDS}

Career anchors. Job satisfaction. Job security. Job stability. Education institution. 


\section{INTRODUCTION}

There are two perspectives that we need to analyze when studying career: the external and the internal one. Whilst the external career is linked to the organization and/or the profession, the internal one concentrates in the aspirations of career, values, perceptions and reactions that individuals have in relation to their work (Igbaria, Kassicieh, \& Silver, 1999; Igbaria \& Baroudi, 1993; Schein, 1983).

Career orientation is made up of individual preferences related to the labor market, which stabilizes and serves as a basis for career decisions. They are present in the professional development of individuals throughout their lives and are objects of studies that seek to discover about this process of decision-making (Silva, Balassiano, \& Silva, 2014; Schein, 1996a, 1984; Hall, 2004; Chapman \& Brown, 2014; Petroni, 2000; Tinti, Venelli-Costa, Vieira, \& Cappellozza, 2017).

Among the studies undertaken to understand aspects of career decision is that by Edgar Schein, termed as Career Anchors. This concept was defined as the self-perception of talents, values and needs, which combined, become a guide for professional choices. According to the idealizer, through the experiences of work and life, some individuals can be aware of their career anchor, thus remaining stable and influencing throughout professional life (Schein, 1983, 1990, 1996a, 1996b).

The lack of knowledge on career anchor can bring about a loss in the professional life as to the quality of their choices and, according to Schein (1996a), when one is aware about the career anchor and seeks to link it to the work environment, the possibility of the worker's satisfaction increases.

Some studies previously conducted on this subject sought to identify the anchors, analyzed the existence of multiple or complementary anchors, related them to emotional intelligence, organizational commitment and demographic variables (Chapman \& Brown, 2014; Wils, Wils, \& Tremblay, 2010; Ituma \& Simpson, 2007; Igbaria et al., 1999; Cantarelli, Estivalete, \& Andrade, 2014). One of the few studies we found addressing satisfaction was by Coetzee and Schreuder (2011), that addressed the satisfaction with the employability that is not the focus of this research.

Considering the studies by Brayfield and Rothe (1951), and Aziri (2011), who recognized job satisfaction to obtain good results in the effectiveness of people management processes, this study set out to answer the question: What is the relationship between job satisfaction of public servants with the career anchors construct, based on the talents, needs, and values of individuals? 
From there we developed the study by means of the construction of the theoretical base, opting for the classification of eight career anchors, demonstrating its characteristics as well as the importance of the analysis of job satisfaction in the organizational environment to improve work processes (Aziri, 2011). Subsequently, we presented the adopted quantitative research methodology, with the application of a questionnaire based on the authors Igbaria and Baroudi (1993) and Netemeyer et al. (1996) in order to identify the existence of a relationship between career anchors and job satisfaction. Finally, after the analysis of the results, we identified the anchors that positively related to job satisfaction. At the end of the study, we made considerations, limitations and proposals for future research to contribute to the theme.

The practical contribution of the research is to provide a diagnosis of the degree of job satisfaction of public servants by analyzing aspects such as remuneration, promotion, immediate leadership, senior management and co-workers, and the relationship with career anchors. From the results, the information we obtained can help in the construction of policies in the areas of competition, personnel training, personnel allocation and career development. As for the theoretical contribution, it provides the expansion of career studies, more specifically in career orientation, where we identified some anchors with a positive relation with job satisfaction.

\section{THEORETICAL FRAMEWORK}

\subsection{Career anchors}

Faced with the complexity of modern life and the impacts generated in the labor market, people's attitudes towards their career were also affected. Research has identified a proactive action in the professional development to maintain employability (Baruch, 2004; Duys, Ward, Maxwell, \& EatonComerford, 2008).

Many reasons have led employees to change their careers. Among them, there are: the reduction of formal employment, shift in career or work posts, changes in lifestyle, points of view about the future and their relation to work (Chanlat, 1995; Igbaria et al., 1999; Coetzee \& Schreuder, 2008; Singh, Bhattacharjee, \& Kodwani, 2009).

Amid the changes, whether personal or environmental, individuals draw new career paths analyzing professional and personal aspects (Hall, 2004; 
Kilimnik, Souza, Oliveira, \& Barros, 2008; Chanlat, 1996; Silva, Dias, Silva, Krakauer, \& Marinho, 2012). Hall (2004), in studying this aspect developed the concept of the protean career, in which he compared the employee's adaptations amidst the constant changes with the figure of the Greek god Proteus, who changed his form based on his interests.

These career changes in which there is shift from academic training or organization are sought to meet the yearnings that go beyond the work environment, in which career development must be connected to aspects such as self-development, personal and family life (Schein, 1983).

The changes throughout the professional life, according to research data by Rodrigues, Guest, and Budjanovcanin (2013) as well as in the studies by Schein (1996a, 1983, 1990, 1996b), show that most people have relatively stable careers guidance, which Schein (1983) termed as Career Anchors.

Career anchors had its seminal study in the 1960s, when individuals were interviewed at various points in their careers and their work attitudes were analyzed in the face of professional changes and choices. We identified that, despite varied stories, there was a standardization as to the motives regarding the changes and choices of work (Schein, 1983, 1984, 1990, 1996a).

In the initial proposed model, we identified five career anchors, which later became eight, namely: Technical/Functional Competence, Managerial Competence, Security/Stability, Autonomy/Independence, Creativity/ Entrepreneurship, Service/Dedication to a Cause, Pure Challenge and Lifestyle (Schein, 1990).

For the construction of the collection instrument, we used the career anchors construct - reduced version by Igbaria and Baroudi (1993). Through the questionnaire, we can identify the career anchor of the individual among the eight established by Schein (1990), which can be summarized as follows:

- Technical/Functional Competence Anchor (TF): The individual who possesses this anchor seeks meaning in the content of their work. They want to build their career in their area of expertise, solving complex problems and being recognized by the exercise of their talents. Their desire to do the tasks in the best way that runs up against the budgetary financial limitations of the organization. They do not look forward to a promotion for general management but rather to be recognized by the level of skill, education and work experience. They seek financial equity compared with professionals from other companies with the same experience and still value self-development opportunities in their area (Schein, 1983; Oswaldo, Cremonezi, Fernandes, Veronesi, \& Oliveira, 2015). 
- Managerial Competence Anchor (MC): The individual who possesses this anchor pursues their career towards the top of the organization. For this purpose, they need to prepare themselves with analytical, interpersonal and emotional relationship skills. They desire high levels of responsibility, challenges, integration of employees and opportunities that provide the success of their organization. As for financial aspects, they want to be well paid and to receive short-term rewards as a bonus for achieving established goals (Schein, 1983).

- Autonomy/Independence Anchor (AI): The individual with this anchor do not like to be bound by rules, procedures, fixed schedules; they need to do things their own way and pace. They have a hard time in an organizational environment because they find it restrictive and invasive of their private lives. Thus, they seek alternatives that give them more freedom and autonomy, and may deny opportunities for financial improvement or promotion, which will remove these desired premises. The type of work must have clear goals and systems of payments for performance, immediate returns and bonuses, as well as benefits according to their needs (Schein, 1983).

- Security/Stability Anchor (SE): The individual who holds this anchor is more concerned with the context than with the nature and challenges of work. Regarding the remuneration aspects, they prefer to receive predictable and stable values throughout their career and that provides them with retirement benefit packages. The recognition in this professional is tied to their loyalty and to the continuous performance of their tasks that guarantees them stability and maintenance of the job (Schein, 1983).

- Creativity/Entrepreneurship Anchor (CE): The individual with this anchor has the desire to create their own business by developing a product or service. They cannot stay in traditional organizations for a long time or use them for partially financing the construction of their own company (Schein, 1983).

- Service/Dedication to a Cause Anchor (SD): The individual who possesses this anchor makes their professional choices toward the values they consider important, a cause that they consider primordial and the desire to change the world in some way. They value the work that enables them to achieve their core values and want to receive a fair payment in return for their contribution (Schein, 1983; Kniveton, 2004).

- Pure Challenge Anchor (DP): The individual who possesses this anchor seeks to tackle difficult challenges and problems, regardless of 
the type. Their preparation is in proving for themselves, and for others, their superiority in the competitive business environment (Schein, 1983).

- Lifestyle Anchor (EV): The individual who possesses this anchor seeks in their professional life to reconcile their personal and professional life. Flexibility, part time work, layoffs and leave are important benefits in the decisions of the professional choices (Schein, 1983; Igbaria et al., 1999).

We use the anchor metaphor to explain that when the individual moves away from their central career orientation tendencies, without the alignment of talents, needs and values, tension and consequent dissatisfaction are generated (Chapman \& Brown, 2014). To collaborate with this matter, Schein (1996a) suggests that the individual knows his/her career anchor, through professional experiences that consolidate, until they reach a situation of stability that will guide professional choices.

While Schein (1996a) established in his studies that each individual has only one career anchor, Feldman and Bolino (1996) propose that people may have primary and secondary career anchors. Other studies have also analyzed whether individuals have one or multiple anchors (Rodrigues, Bouzada, \& Kilimnik, 2007; Ituma \& Simpson, 2007). This study followed the idea that each individual possesses a career anchor (Schein, 1996a) and we performed the identification of the anchor using the data obtained in the adopted questionnaire (Igbaria \& Baroudi, 1993).

Having a career anchor does not mean stagnation, but recognition that in the same academic formation there is a variety of possibilities in career choices, tied to individual talents, values and needs (Feldman \& Bolino, 1996; Schein, 1996a). Moreover, because of the many layoffs and the need to find out about their next career choices Schein (1996a) affirms the importance of the knowledge about anchors in career development.

From the studies that identified the career anchors of the respondents, we highlight the study by Vasconcelos, Merhi, Goulart, \& Silva (2010), confirming the trend already foreseen by Schein (1996a), on the increasing representativeness of the Lifestyle anchor. One of the indications for this result lies in the changes related to the psychological contracts of work with a search for the workers to meet personal and organizational expectations (Baruch, 2004; Balassiano, Ventura, \& Fontes Filho, 2003; Faro, Amorim, Trevisan, \& Junqueira, 2010).

One of the objectives of Schein (1996a) to stimulate self-knowledge of talents, needs and values through career anchors is to provide the individuals 
to make the most congruent professional choices and thus bring positive reflexes to job satisfaction.

\subsection{Job satisfaction}

In contemporary companies, we find workers with protean attitudes in search of satisfying their desires and needs. Job satisfaction has gained space in organizational environments because it generates effects related to productivity, motivation, loyalty, productivity, and business performance (Aziri, 2011).

The definition by Spector (1997) for job satisfaction is the way people feel about their job in its various aspects. For Davis and Newstrom (1992), it is directly related to the favorable feeling or not of the individual with their job. Regarding the degree of job satisfaction, it can vary from extreme satisfaction to extreme dissatisfaction, observing aspects such as the type of work, the relationship between colleagues, bosses and subordinates, as well as the salary (Lan, Okechuku, Zhang, \& Cao, 2013).

Roberts and Foti (1998) identified job satisfaction in people who felt their abilities, experiences and values applied in their organizational environment and that such contributions reverted to opportunities and rewards. Studies by Sarker, Crossman, and Chinmeteepituck (2003) sought to understand the relationship between productivity and permanence in the organization with job satisfaction. As for Clark, Oswald, and Warr (1996), they identified the relationship with demographic variables such as age, gender and race.

Satisfaction relates much to the individual's perception and assessment of their job with influences of the individualities of each person based on their needs, values and expectations (Buitendach \& Rothmann, 2009). Understanding this fact is not a simple, but a necessary task for organizations in relation to training, that need to be aware of the particularities of individuals (Aziri, 2011; Code \& Code, 2014).

In addition, the junction of intrinsic and extrinsic factors makes the job satisfaction variable complex, because whilst these are related to work environment situations, those deal with the particularity of each individual connected to the tasks performed at work (Rothmann \& Agathagelou, 2000). It is worth remembering that according to Kong, Wang, and $\mathrm{Fu}$ (2015) these factors contribute to job satisfaction.

Spector (1997) warns that organizations should be concerned to treat their employees in a fair and respectful manner, observing human values, 
since both the influence of external and internal factors can cause job satisfaction or dissatisfaction. At the same time that job satisfaction brings positive results for companies; dissatisfaction generates problems like lack of loyalty, increase of absenteeism, strike and accidents of work (Aziri, 2011).

The performance of work whose characteristics are inconsistent with their values can have consequences such as dissatisfaction, anxiety, boredom and irritation, as well as an undesired performance (Kristof-Brown, Zimmerman, \& Johnson, 2005; Edwards \& Van Harrison, 1993). The adjustment between job demands and personal characteristics is positively related to increased employee satisfaction, happiness and well-being (Kristof, 1996; Vancouver \& Schmitt, 1991).

Amongst the measures to place the individual with better job and organization adjustment are the selection process and adoption of socialization, training and learning policies (Kristof-Brown et al., 2005; Schneider, Goldstein, \& Smith, 1995; Gabriel, Diefendorff, Chandler, Moran, \& Greguras, 2014). An organizational policy cannot be achieved for each employee, and empirical studies help identify factors which may be common to workers and their intervention on job satisfaction for the construction of more adequate policies (Christiansen, Sliter, \& Frost, 2014).

In the study carried out by Borges (2013), it was identified that the worker in the public sector is more satisfied than those in the private sector in terms of stability; however, with regard to growth and compensation this situation is reversed.

Thus, we can say that public institutions are not exempt from having unsatisfied public servants in their offices; they need to be attentive to the satisfaction of their employees, as it relates to productivity and engagement. Understanding the factors that explain satisfaction becomes a tool for better managing employee performance in performing their tasks (Taylor, 2014).

In this regard, we chose a study of job satisfaction that analyzed five dimensions: pay, progression, immediate leadership, senior management and co-workers (Netemeyer et al., 1996).

\subsection{Career anchors and job satisfaction}

While some companies expect their employees to take responsibility for their careers, others feel it is already enough to offer training courses, learning practices and career development at work. In fact, organizations need not only to be concerned with the demands of work but also with the ambitions and preferences of employees to guide and monitor professional development (Vos \& Hauw, 2010; Kidd, Hirsh, \& Jackson, 2004; Vermeulen, 2015). 
When there is a congruence between the career anchor and the working environment, we identify positive results in relation to career, and organizations need to realize that the adjustment between employee values and the work environment is a relevant indicator for job satisfaction (Feldman \& Bolino, 1996).

As part of career development, people need to be aware of the motives, values, and needs that govern their professional decisions, and the career anchors tool is a support in career choices, life and job satisfaction, and career satisfaction (Coetzee \& Schreuder, 2010).

In the same organization, we can find several Anchors, and the compatibility between the desires and aspirations of the workers and their work produce positive relation of job satisfaction (Igbaria, Greenhaus, \& Parasuraman, 1991). Gerpott, Domsch, and Keller (1988) in their study conducted among research and development professionals in Germany, England and the United States, verified the importance of career orientation in relation to job satisfaction.

According to Leong, Rosenberg and Chong (2013), individuals should have higher job satisfaction when the job specialization corresponds to their career anchor. A tool can also help management to take note of the various career orientations of employees and use to select the employee for the most suitable working position (Igbaria et al., 1999).

We can infer the employee's satisfaction with respect to their work based on the individual's attitudes toward their work environment (Brayfield \& Rothe, 1951). Taylor (2014) demonstrated the importance of job satisfaction for the organization's performance.

The present study analyzed the existence of a relation of job satisfaction with the construct denominated career anchors (Schein, 1996a; 1996b), with it being an instrument of self-analysis based on the values, needs and talents of the individuals to conduct the career choices.

Thus, it emerged the hypotheses of this study that propose to relate career anchors with job satisfaction, which follow below:

H1: 1. The Technical Functional Competence Anchors; 2. Managerial Competence; 3. Autonomy/Independence; 4. Security/Stability; 5. Creativity/ Entrepreneurship; 6. Service/Dedication to a cause; 7. Pure Challenge; 8. Lifestyle is positively related to satisfaction with remuneration.

H2: 1. The Technical Functional Competence Anchors; 2. Managerial Competence; 3. Autonomy/Independence; 4. Security/Stability; 5. Creativity/ Entrepreneurship; 6. Service/Dedication to a cause; 7. Pure Challenge; 8. Lifestyle is positively related to satisfaction with promotion. 
H3: 1. The Technical Functional Competence Anchors; 2. Managerial Competence; 3. Autonomy/Independence; 4. Security/Stability; 5. Creativity/ Entrepreneurship; 6. Service/Dedication to a cause; 7. Pure Challenge; 8. Lifestyle is positively related to satisfaction with the immediate superior.

H4: 1. The Technical Functional Competence Anchors; 2. Managerial Competence; 3. Autonomy/Independence; 4. Security/Stability; 5. Creativity/ Entrepreneurship; 6. Service/Dedication to a cause; 7. Pure Challenge; 8. Lifestyle is positively related to the satisfaction with senior management.

H5: 1. The Technical Functional Competence Anchors; 2. Managerial Competence; 3. Autonomy/Independence; 4. Security/Stability; 5. Creativity/ Entrepreneurship; 6. Service/Dedication to a cause; 7. Pure Challenge; 8. Lifestyle is positively related to satisfaction with co-workers.

H6: 1. The Technical Functional Competence Anchors; 2. Managerial Competence; 3. Autonomy/Independence; 4. Security/Stability; 5. Creativity/ Entrepreneurship; 6. Service/Dedication to a cause; 7. Pure Challenge; 8. Lifestyle is positively related to overall satisfaction.

\section{METHODOLOGY}

To perform our research, in which we relate job satisfaction with career anchors, we used a cross-sectional quantitative approach, with primary data and a non-probabilistic sample type, due to the ease of access to the research (Guimarães, 2012).

We chose the Federal Institute of Espírito Santo (IFES), a public authority in the area of education that offers technical and higher education courses, chosen as the population for our study, since it covers a group of about 2,500 public servants working as lecturers or as administrative support in its units distributed in the capital and in the countryside of Espírito Santo.

The sample contained 671 public servants of the campuses and the rectory of this Institute, a response rate of $27 \%$, covering a group diversified in relation to age, gender, locality, and functional category.

In December of 2015, we distributed the questionnaires in one of the campuses and in the period from March to June of 2016, and we distributed them to the other campuses and rectory. We discarded thirty-one questionnaires that respondents did not complete in their entirety.

We based the distributed questionnaire on studies by Igbaria and Baroudi (1993) and Netemeyer et al. (1996). The Committee of Ethics in 
Research with human beings of Ifes (CEP/IFES) approved both, the questionnaire and the research project.

The questionnaire was composed of 25 assertions that included the eight career anchors using a five-point Likert scale ranging from 1 to 5 , where in assertions from 1 to 15, 1 indicated "unimportant to me" and 5, "extremely important to me". While in assertions from 16 to 25,1 indicated, "nothing is true for me" and 5, "totally true to me".

On the other hand, the assertions regarding job satisfaction included a five-dimensional analysis: compensation, promotion, immediate leadership, senior management, co-workers and an overall satisfaction analysis. We also adopted the Likert scale; however, of 7 points. In assertions from 26 to 31 , the range of variation was from 1 to 7 , where 1 indicated "I am very dissatisfied" and 7, "I am totally satisfied".

We applied the research with public servants of the Institute, with it initially being held in one of the campuses (pre-test), and we sent the questionnaire in three formats: by e-mail, electronically and through paper survey method, this being the one that obtained the most return of answers. The sample for analysis of the relationship between job satisfaction and career anchors was composed only of individuals who presented the identification of a career anchor, i.e., 610 (91\%) of respondents.

We calculated the reliability measure of the questionnaire using Cronbach's Alpha, and the questions related to job satisfaction were 0.95, and those related to career anchor ranged from 0.55 to 0.86 , values that are mostly close to the recommended minimum of 0.70 (Hair, Black, Babin, Anderson, \& Tatham, 2009; Almeida, Santos, \& Costa, 2010).

For the preparation, acquisition and storage of information in electronic format, we used the "Google Docs" tools and transferred to the spreadsheet format in the preparation of the data for the analysis of basic statistics and multiple regression using the Stata software.

\section{ANALYSIS OF DATA AND RESULTS}

\subsection{Characterization of the sample}

The sample of this research was composed of working public servants of all the campuses and the rectory of Ifes. There were 671 public servants, of which 428 administrative support (TAE) and 243 teaching staff (DOC). As for gender, in the case of administrative support servants, $55 \%$ are female 
and $45 \%$ are male, which differs from the teaching staff, in which the majority is male $(77 \%)$, against $23 \%$ female. Moreover, the predominant marital status is married/stable union, with $65 \%$ of servants.

At each Ifes campus, the sectors are classified as the administrative or teaching staff departments, and the percentage was $58 \%$ for the teaching staff area and $42 \%$ for the administrative area. As for the number of public servants who occupy management activities (gratified function, position of trust and course coordination), it corresponded to $31 \%$ of the sample.

The educational control variable differs in the administrative and teaching staff categories; whereas for the teaching staff the concentration is in the masters with $51 \%$, and in the administrative, it is in the specialization, with $55 \%$.

More than $50 \%$ of the sample is concentrated between the ages of 30 and 44 years and about $80 \%$ of the employees have up to 10 years of service in the institution, still in early career.

\subsection{Data analysis}

\subsubsection{Identification of career anchors}

After applying the questionnaire, identifying the career anchors of the campus's public servants, we found individuals with more than one anchor. Of the 671 respondents, $610(91 \%)$ were identified with a predominant anchor and 60 (9\%) with two or more anchors.

Of the servants that had a career anchor, Pure Challenge was represented by $4.75 \%$ and - even though it is an expected result, considering that the sample is of public servants -, it was ahead of the representation of the anchors Technical Functional Competence, Managerial Competence, Autonomy/Independence, and Creativity/Entrepreneurship.

The Managerial Competence anchor had a very low representation in the personnel of the institution, a factor that is worrying for management in the designation of the managerial boards. The sample indicated a percentage of $31 \%$ of occupants of management position; however only $2.62 \%$ presented the Managerial Competence anchor, from which we can infer that most managers can perform this task without being adjusted with the duties and responsibilities of the work position. In another study done in a public institution, developed by Cantarelli et al. (2014), this anchor also presented low representativeness.

On the other hand, public servants with the Service/Dedication to a cause, Security/Stability and Lifestyle anchor represented $74 \%$ of the sample 
that only had an anchor identification. Cantarelli et al. (2014) also identified the predominance of these three anchors in the establishment plan in a percentage of $70 \%$, as well as in the study by Igbaria et al. (1999) with engineering professionals.

Of the eight anchors established by Schein (1996a), the concentration in this research occurred in three: Service/Dedication to a cause, 354 public servants (58.03\%); Security/Stability, 102 public servants $(16.72 \%)$ and, finally, Lifestyle, 97 public servants (15.90\%), making a total of 553 public servants (91\%), result also found by Petroni (2000), Faro et al. (2010), Coetzee and Schreuder (2011), and Cantarelli et al. (2014).

Public servants identified holding the Service/Dedication to a Cause Anchor, which represent $58.03 \%$, seek a harmonious environment between people and the achievement of a job that improves society (Schein, 1996a; Kniveton, 2004).

Although not the most representative, the Lifestyle Anchor appears as number 3. This did not come as a surprise since Schein (1996a) had predicted this trend, as observed in the studies by Vasconcelos et al. (2010) as a consequence of the changes in the labor market and the search of the individual for integrating personal, family and professional needs (Baruch, 2004; Balassiano et al. 2003; Schein, 1996a).

\subsubsection{Relationship of anchors with job satisfaction}

Considering that the establishment plan is divided into two categories with differentiated roles and careers, we chose to analyze it separately in relation to job satisfaction.

The Security/Stability Anchor indicated a positive relation in all dimensions of satisfaction established in this study for Job Satisfaction, for the teaching staff and administrators, with the exception of the "satisfaction with management" dimension. Despite changes occurring in the public environment with the aim of bringing labor rules closer to public servants and employees of private enterprise, security and stability are still attractive elements to enter in the Public Administration sector.

The Technical Functional Competence Anchor did not positively relate to any dimension of job satisfaction for the teaching staff. Whereas the Managerial Competence Anchor did positively relate to satisfaction with promotion for the teaching staff; for the administrative staff it related negatively.

The Creativity/Entrepreneurship Anchor was negatively related to satisfaction with the remuneration, with the promotion and general 
satisfaction for the teaching staff, and for the administrative, it did not relate to any dimension of job satisfaction.

Of the most representative Anchors, the Service/Dedication to a cause Anchor was not related to any dimension of satisfaction for the teaching staff, different from the Security/Stability Anchor, which was related to satisfaction, although its representativeness was only $16.72 \%$. We can infer that much of the sample is not satisfied as a result of its Anchor, but by other variables that are not included in this model.

Whilst for the administrative staff the Service/Dedication to a cause Anchor was positively related to satisfaction with remuneration, promotion and with co-workers; and it did not occur for the teaching staff.

The Pure Challenge and Lifestyle Anchors were positively related to dimensions of job satisfaction. Our results followed the studies by Kniveton (2004), in which the masculine gender was more represented in the Anchors Managerial Competence, Pure Challenge and Autonomy/Independence and in the feminine gender in the Security/Stability Anchor.

The Lifestyle Anchor was a domain of the female gender in the quest to reconcile professional and personal life, as in the study by Rodrigues et al. (2013) and Singh, Bhattacharjee, and Kodwani (2009), as well as the Technical Functional Competence Anchor in the research by Oswaldo et al. (2015).

The administrative staff in a differentiated manner had a positive relation of Service/Dedication to a cause, and Security/Stability Anchors with satisfaction in several dimensions, which allows inferring that in this category the percentage of public servants satisfied due to their Anchor is higher than for the teaching staff.

\section{FINAL CONSIDERATIONS}

This study aimed to relate the career anchors and job satisfaction of public servants, using current federal public servants of Ifes as a sample.

Regarding the identification of the career anchors of the Ifes public servants, $91 \%$ of the sample was classified as Service/Dedication to a cause, Security/Stability and Lifestyle Anchors. The results are in accordance with the test sample carried out in the Serra campus and the findings of the study by Petroni (2000), Faro et al. (2010), Coetzee and Schreuder (2011), and Cantarelli et al. (2014).

Security/Stability Anchors, Dedication/Service to a Cause and Lifestyle are congruent with activities in the public service, however only the Security/ 
Stability Anchor was related to satisfaction in all dimensions for the category of teaching staff and for the administrative, with the exception of satisfaction with the leadership.

The Dedication/Service to a cause anchor also, with greater representativeness of servants, did not obtain any relation of job satisfaction of the teaching staff; as for the administrative staff it was positively related to satisfaction with the remuneration, promotion and with co-workers. Cantarelli et al. (2014) also found in their studies the relation of this Anchor with career satisfaction.

In this study, the Lifestyle Anchor_one of the Anchors pointed out by Schein (1996a) as increasing - had a representation of $15.90 \%$, next to that of the number of public servants with the Security/Stability Anchor (16.72\%). As for the Pure Challenge Anchor, it surprised with positive relation with the satisfaction with management, senior management and co-workers, since the public environment offers little space for people with these characteristics.

Diagnosing public servants dissatisfaction does not solve the institutional problem, but it is the first step in finding ways for better tailoring the individual to their job, making their employees aware of their values and talents, including showing new career alternatives.

In the results, we identified promotion as the lowest public servant satisfaction index. In this study, we did not intend to analyze the details of the aspects that refer to this discontentment, so this clue can help managers to investigate and make proposals that try to reverse this situation. Another topic with low satisfaction rates is related to senior management that can also be better managed to reverse this situation.

The theoretical contribution was to identify that the Security/Stability Anchor, although not the most representative, had significant explanatory power with job satisfaction. Thus we can infer that even respondents being identified with other Anchors prioritize stability at work that offers financial balance (Coetzee \& Schreuder, 2008).

The development of the study has the identification of the Anchors that public servants have as a practical contribution, providing opportunities for self-knowledge of their current career choice based on values, talents and needs, as well as to enable managers of Ifes to allocate their public servants in activities that are more congruent with their career anchors. In addition, alsoto make available for the Institute an updated study on the situation of public servants in relation to their job satisfaction to seek alternatives for improvement in work processes related to people management. 
The low representativeness of individuals identifying themselves with the Managerial Competence Anchor serves to ensure that the Institute invests, in its staff, in the development of leaders, since the institution needs people who manage it by occupying roles/functions.

One of the limitations of this research was the concentration of data in only one institution, and therefore the proposal is to apply future studies in organizations with other characteristics, since Ifes are focused on the area of Education. This study can also be applied in the municipal and federal spheres, where the scope of action is greater both in the services provided and in the diversity of positions involved.

Based on this study, managers can better understand their workforce and through individual, ethical, relationship and group work differences, management can conduct trainings (Coda \& Coda, 2014) to better serve the institution and employees.

\section{SATISFAÇÃO NO IFES: UMA ANÁLISE POR MEIO DAS ÂNCORAS DE CARREIRA}

\section{RESUMO}

Objetivo: O objetivo desta pesquisa é analisar a satisfação no trabalho dos servidores públicos por meio das âncoras de carreira.

Originalidade/relevância: A contribuição desta pesquisa é aplicar um instrumento de coleta em versão reduzida para análise da satisfação no trabalho no serviço público na busca de subsídios para propostas de melhorias nos processos de trabalho relacionados à gestão de pessoas.

Principais aspectos metodológicos: A pesquisa foi realizada com 671 servidores de uma autarquia da área de ensino público. Como instrumento de coleta foi utilizado questionário enviado por e-mail, método de survey eletrônico e em papel. O questionário foi baseado no "Inventário de Âncora de Carreira”- adaptada por Igbaria e Baroudi (1993) e no trabalho de Netemeyer et al. (1996), denominado "Satisfação Global no Trabalho".

Síntese dos principais resultados: Os resultados apresentados identificaram que a âncora Segurança/Estabilidade foi relacionada com satisfação no trabalho tanto para os servidores docentes quanto para 
os administrativos, enquanto a âncora Serviço/Dedicação, a uma Causa só, foi relacionada para os servidores administrativos. A pesquisa também identificou baixa representatividade de indivíduos com a âncora Competência Gerencial.

\section{PALAVRAS-CHAVE}

Âncoras de carreira. Satisfação no trabalho. Segurança no trabalho. Estabilidade no trabalho. Instituição de ensino.

\section{DEFERENCES}

Almeida, D., Santos, M. D., \& Costa, A. F. B. (2010, October). Aplicação do coeficiente alfa de Cronbach nos resultados de um questionário para avaliação de desempenho da saúde pública. Paper presented at the Encontro Nacional de Engenharia de Produção, São Carlos, SP, Brazil, 10-15.

Aziri, B. (2011). Job satisfaction: A literature review. Management research and practice, 3(4), 77-86.

Balassiano, M., Ventura, E. C. F., \& Fontes Filho, J. R. (2003). Carreiras e cidades: Existe um melhor lugar para se fazer carreira. Proceedings of the Encontro da Associação Nacional de Pós-Graduação e Pesquisa em Administração (Enanpad), Atibaia, SP, Brazil, 27.

Baruch, Y. (2004). Transforming careers: From linear to multidirectional career paths: Organizational and individual perspectives. Career development international, 9(1), 58-73. doi:10.1108/13620430410518147

Borges, R. (2013). Are public officials really less satisfied than private sector workers? A comparative study in Brazil. Revista de Administração Pública, 47(6), 1477-1496.

Brayfield, A. H., \& Rothe, H. F. (1951). An index of job satisfaction. Journal of applied psychology, 35(5), 307-311. doi:10.1037/h0055617

Buitendach, J. H., \& Rothmann, S. (2009). The validation of the Minnesota job satisfaction questionnaire in selected organizations in South Africa: Original research. SA Journal of Human Resource Management, 7(1), 1-8. doi:10.4102/sajhrm.v7i1.183 
Cantarelli, N. M., Estivalete, V. F. B., \& Andrade, T. de. (2014). Âncoras de carreira e comprometimento organizacional: Ampliando a sua compreensão. Revista Base da Unisinos, 11 (2), 153-166. doi:10.4013/base.2014.112.05

Chanlat, J. F. (1995). Quais carreiras e para qual sociedade? Revista de Administração de Empresas, 35(6), 13-20.

Chanlat, J. F. (1996). Quais carreiras e para qual sociedade? Revista de Administração de Empresas, 36(1), 13-20. doi:10.1590/S0034-759019960001 00003

Chapman, J. R., \& Brown, B. L. (2014). An empirical study of the career anchors that govern career decisions. Personnel Review, 43(5), 717-740. doi:10.1108/PR-01-2013-0017

Christiansen, N., Sliter, M., \& Frost, C. T. (2014). What employees dislike about their jobs: Relationship between personality-based fit and work satisfaction. Personality and Individual Differences, 71, 25-29. doi:10.1016/j. paid.2014.07.013

Clark, A., Oswald, A., \& Warr, P. (1996). Is job satisfaction Ushaped in age? Journal of Occupational and Organizational Psychology, 69(1), 57-81. doi:10.1111/j.2044-8325.1996.tb00600.x

Coda, R., \& Coda, D. A. (2014). Strategic performance of the human resources management department: An exploratory research on the implications from the behavioral styles of its professionals. Brazilian Business Review, 11 (4), 107. doi:10.15728/bbr.2014.11.4.5

Coetzee, M., \& Schreuder, D. (2008). A multi-cultural investigation of students' career anchors at a South African higher education institution. South African Journal of Labour Relations, 32(2), 45-65.

Coetzee, M., \& Schreuder, D. (2010). The influence of career orientations on subjective work experiences: Original research. SA Journal of Human Resource Management, 8(1), 1-13. doi:10.4102/sajhrm.v8i1.279

Coetzee, M., \& Schreuder, D. (2011). The relation between career anchors, emotional intelligence and employability satisfaction among workers in the service industry. Southern African Business Review, 15(3), 76-97.

Davis, K., \& Newstrom, J. W. (1992). Comportamento humano no trabalho: Uma abordagem psicológica. Santana de Parnaíba: Pioneira.

Duys, D. K., Ward, J. E., Maxwell, J. A., \& Eaton-Comerford, L. (2008). Career counseling in a volatile job market: Tiedeman's perspective revisited. The Career Development Quarterly, 56(3), 232-241. doi:10.1002/j. 2161-0045.2008.tb00037.x 
Edwards, J. R., \& Van Harrison, R. (1993). Job demands and worker health: Three-dimensional reexamination of the relationship between personenvironment fit and strain. Journal of Applied Psychology, 78(4), 628. doi:10.1037/0021-9010.78.4.628

Faro, E. S. C., Amorim, M. C. S., Trevisan, L., \& Junqueira, L. A. P. (2010). Âncoras de carreira e transformações no modelo de administração: Estudo de caso do Tribunal de Contas da União (TCU). Cadernos Ebape, 8(4), 710-733.

Feldman, D. C., \& Bolino, M. C. (1996). Careers within careers: Reconceptualizing the nature of career anchors and their consequences. Human Resource Management Review, 6(2), 89-112. doi:10.1016/S10534822(96)90014-5

Gabriel, A. S., Diefendorff, J. M., Chandler, M. M., Moran, C. M., \& Greguras, G. J. (2014). The dynamic relationships of work affect and job satisfaction with perceptions of fit. Personnel Psychology, 67(2), 389-420. doi:10.1111/ peps. 12042

Gerpott, T. J., Domsch, M., \& Keller, R. T. (1988). Career orientations in different countries and companies: An empirical investigation of West German, British and US industrial R\&D professionals. Journal of Management Studies, 25(5), 439-462. doi:10.1111/j.1467-6486.1988.tb00709.x

Guimarães, P. R. B. (2012). Métodos quantitativos estatísticos. Curitiba: Iesde Brasil S.A.

Hall, D. T. (2004). The protean career: A quarter-century journey. Journal of vocational behavior, 65(1), 1-13. doi:10.1016/j.jvb.2003.10.006

Igbaria, M., \& Baroudi, J. J. (1993). A short-form measure of career orientations: A psychometric evaluation. Journal of Management Information Systems, 10(2), 131-154. doi:10.1080/07421222.1993.11518003

Igbaria, M., Greenhaus, J. H., \& Parasuraman, S. (1991). Career orientations of MIS employees: An empirical analysis. MIS quarterly, 151-169. doi: $10.2307 / 249376$

Igbaria, M., Kassicieh, S. K., \& Silver, M. (1999). Career orientations and career success among research, and development and engineering professionals. Journal of Engineering and technology management, 16(1), 29-54. doi:10.1016/S0923-4748(98)00027-7

Ituma, A., \& Simpson, R. (2007). Moving beyond Schein's typology: Individual career anchors in the context of Nigeria. Personnel Review, 36(6), 978-995. doi:10.1108/00483480710822463 
Kidd, J. M., Hirsh, W., \& Jackson, C. (2004). Straight talking: The nature of effective career discussion at work. Journal of Career Development, 30(4), 231-245. doi:10.1023/B:JOCD.0000025113.48212.75

Kilimnik, Z. M., Anna, S., Souza, A. de, Oliveira, L. C. V. D., \& Barros, D. T. R. (2008). Seriam as âncoras de carreiras estáveis ou mutantes? Um estudo com profissionais de Administração em transição de carreira. Revista Brasileira de Orientação Profissional, 9(1), 43-60.

Kniveton, B. H. (2004). Managerial career anchors in a changing business environment. Journal of European industrial training, 28(7), 564-573. doi:10. 1108/03090590410549984

Kong, H., Wang, S., \& Fu, X. (2015). Meeting career expectation: Can it enhance job satisfaction of Generation Y? International Journal of Contemporary Hospitality Management, 27(1), 147-168. doi:10.1108/IJCHM-08-20130353

Kristof, A. L. (1996). Person-organization fit: An integrative review of its conceptualizations, measurement, and implications. Personnel Psychology, 49(1), 1-49. doi:10.1111/j.1744-6570.1996.tb01790.x

Kristof-Brown, A. L., Zimmerman, R. D., \& Johnson, E. C. (2005). Consequences of individual's fit at work: A meta-analysis of person-job, person-organization, person-group, and person-supervisor fit. Personnel Psychology, 58(2), 281-342. doi:10.1111/j.1744-6570.2005.00672.x

Hair, J. F., Black, W. C., Babin, B. J., Anderson, R. E., \& Tatham, R. L. (2009). Análise multivariada de dados. São Paulo: Bookman Editora.

Lan, G., Okechuku, C., Zhang, H., \& Cao, J. (2013). Impact of job satisfaction and personal values on the work orientation of Chinese accounting practitioners. Journal of Business Ethics, 112(4), 627-640. doi:10.1007/s105 51-012-1562-5

Leong, F. T., Rosenberg, S. D., \& Chong, S. (2013). A psychometric evaluation of Schein's (1985) career orientations inventory. Journal of Career Assessment, 22 (3), 524-538. doi:10.1177/1069072713498685

Netemeyer, R. G., Boles, J. S., \& McMurrian, R. (1996). Development and validation of work-family conflict and family-work conflict scales. Journal of Applied Psychology, 81 (4), 400. doi:10.1037/0021-9010.81.4.400

Oswaldo, Y. C., Cremonezi, G. O. G., Fernandes, M. de A., Veronesi, R., \& Oliveira, F. M. de. (2015). La relación entre gestión de carrera y aspectos culturales en instituciones de enseñanza superior. Invenio: Revista de Investigación Académica, (34), 23-33. 
Petroni, A. (2000). Strategic career development for R\&D staff: A field research. Team Performance Management: An International Journal, 6(3/4), 52-62. doi:10.1108/13527590010731970

Roberts, H. E., \& Foti, R. J. (1998). Evaluating the interaction between selfleadership and work structure in predicting job satisfaction. Journal of Business and Psychology, 12(3), 257-267. doi:10.1023/A:1025067128193

Rodrigues, C. L. M., Bouzada, V. C. P., \& Kilimnik, Z. M. (2007). Estilo de vida e segurança: Seriam essas as âncoras dos futuros detentores de carreiras proteanas ou sem fronteiras? Um estudo comparativo entre alunos de graduação e de mestrado em Administração. Proceedings of the Congresso Virtual Brasileiro de Administração (Convibra), Brazil, 3.

Rodrigues, R., Guest, D., \& Budjanovcanin, A. (2013). From anchors to orientations: Towards a contemporary theory of career preferences. Journal of Vocational Behavior, 83(2), 142-152. doi:10.1016/j.jvb.2013.04.002

Rothmann, S., \& Agathagelou, A. M. (2000). Die verband tussen lokus van beheer en werkstevredenheid by senior polisiepersoneel. SA Journal of Industrial Psychology, 26(2), 20-26. doi:10.4102/sajip.v26i2.703

Sarker, S. J., Crossman, A., \& Chinmeteepituck, P. (2003). The relationships of age and length of service with job satisfaction: An examination of hotel employees in Thailand. Journal of Managerial Psychology, 18(7), 745-758. doi:10.1108/02683940310502421

Schein, E. H. (1983). Individuals and careers. Cambridge, MA: MIT Press.

Schein, E. H. (1984). Culture as an environmental context for careers. Journal of Organizational Behavior, 5(1), 71-81. doi:10.1002/job.4030050107

Schein, E. H. (1990). Career anchors and job/role planning: The links between career pathing and career development. MIT Sloan School of Management. Retrieved from https://dspace.mit.edu/handle/1721.1/2315

Schein, E. H. (1996a). Career anchors revisited: Implications for career development in the 21 st century. The Academy of Management Executive, 10(4), 80-88.

Schein, E. H. (1996b). Identidade profissional: Como ajustar suas inclinações a suas opções de trabalho. São Paulo, SP: Nobel.

Schneider, B., Goldstein, H. W., \& Smith, D. B. (1995). The ASA framework: An update. Personnel Psychology, 48(4), 747-773. doi:10.1111/j.1744-6570. 1995.tb01780.x 
Silva, J. R., Balassiano, M., \& Silva, A. R. L. da. (2014). Burocrata Proteano: Articulações de Carreira em torno e além do Setor Público. Revista de Administração Contemporânea, 18(1), 1-19. doi:10.1590/S1415-655520140001 00002

Silva, R. C., Dias, C. A. F., Silva, M. T. G. da, Krakauer, P. V. C., \& Marinho, B. L. (2012). Carreiras: novas ou tradicionais? Um estudo com profissionais brasileiros. Revista de Carreiras e Pessoas (ReCaPe), 2(1). doi:10.20503/recape. v2i1.9337

Singh, M. K., Bhattacharjee, V., \& Kodwani, A. D. (2009). Mapping career anchors in a large engineering company: A study. Paradigm, 13(2), 50-56. doi:10.1177/0971890720090207

Spector, P. E. (1997). Job satisfaction: Application, assessment, causes, and consequences (Vol. 3). Thousand Oaks: Sage Publications.

Taylor, J. (2014). Public service motivation, relational job design, and job satisfaction in local government. Public Administration, 92 (4), 902-918. doi:10.1111/j.1467-9299.2012.02108.x

Tinti, J. A., Venelli-Costa, L., Vieira, A. M., \& Cappellozza, A. (2017). O impacto das políticas e práticas de recursos humanos sobre os comportamentos de cidadania organizacional. Brazilian Business Review, 14(6).

Vancouver, J. B., \& Schmitt, N. W. (1991). An exploratory examination of person-organization fit: Organizational goal congruence. Personnel Psychology, 44(2), 333-352. doi:10.1111/j.1744-6570.1991.tb00962.x

Vasconcelos, K. C., Merhi, D. Q., Goulart, V. M., \& Silva, A. R. L. D. (2010). A geração Y e suas âncoras de carreira. GESTÃO.org - Revista Eletrônica de Gestão Organizacional, 8(2), 226-244.

Vermeulen, L. (2015). Career Anchors and work behavioural style for career management in the South African public service. European Scientific Journal, $11(14)$.

Vos, A., \& Hauw, S. (2010). Linking competency development to career success: Exploring the mediating role of employability. Vlerick Leuven Gent Management School, Working Paper Series. Retrieved from https://public. vlerick.com/Publications/41770ac2-6aa9-e011-8a89-005056a635ed.pdf

Wils, L., Wils, T., \& Tremblay, M. (2010). Toward a career anchor structure: An empirical investigation of engineers. Relations industrielles/Industrial relations, 65(2), 236-256. doi:10.2307/23078339 


\section{AUTHOR NOTE}

Rosângela C. Vargas, Fundação Instituto Capixaba de Pesquisas em Contabilidade, Economia e Finanças (Fucape); Aridelmo Teixeira, Fucape.

Rosângela C. Vargas is now an administrator of Human Resource Management at Instituto Federal do Espírito Santo (IFES); Aridelmo Teixeira is now a professor at Fucape.

Correspondence concerning this article should be addressed to Aridelmo Teixeira, Avenida Fernando Ferrari, 1358, Boa Vista, Vitória, ES, Brazil, CEP 29075-505.

E-mail: aridelmo@fucape.br

\section{EDITORIAL BOARD}

Editor-in-chief

Silvio Popadiuk

Associated Editor

Luciana M. C. Silva

(iD) https://orcid.org/0000-0002-8230-3763

Technical Support

Vitória B. S. Silva

\section{EDITORIAL PRODUCTION}

Publishing Coordination

Irina Migliari

Language Editor

Daniel Leão

Editorial Trainee

Layout Designer

Maria Luiza Vanz

Emap

Copyeditor

Irina Migliari
Graphic Designer

Libro 